\title{
2 \\ DEN TREDJE STATSMAKT FOR FALL? \\ TYRKISKE DOMSTOLER FøR \\ OG ETTER KUPPFORSøKET
}

\begin{abstract}
e
Siden kuppforsøket sommeren 2016 har jurister uttrykt bekymring for at Tyrkias utøvende myndigheter er i ferd med å sette domstolene til side i sin kamp mot Erdoğans fiender. Men tyrkiske domstoler har lenge vort politiske redskaper. Er domstolenes rolle i endring?
\end{abstract}

JOAKIM PARSLOW

Som leder for Tyrkias største parti, statsminister i tre perioder og president i to, har Recep Tayyip Erdoğan nå dominert tyrkisk politikk i 16 år. I løpet av den tiden har Erdoğan og hans Rettferdsog utviklingsparti (Adalet ve Kalkınma Partisi, AKP) gått fra å være både Tyrkias og Vestens yndling til å bli gjenstand for dyp polarisering i Tyrkia og kraftig kritikk fra amerikanske og europeiske ledere. Mye av den utviklingen skyldes hvordan forholdet har endret seg mellom Erdoğan og loven - og domstolene som skal håndheve den.

AKP ble først valgt inn i Nasjonalforsamlingen i november 2002 med løfte om å fortsette prosessen som hadde pågått siden 2001 med å liberalisere lovgivningen rundt etniske og religiøse identiteter og styrke rettssikkerheten. ${ }^{1}$ Til tross for skepsis fra Tyrkias sekularister ble løftene holdt i stor nok grad til at Tyrkia i oktober 2005 kunne starte formelle medlemsskapsforhandlinger med EU. Da AKP vant gjenvalget i 2007, og fikk sin partifelle Abdullah Gül valgt til president i 2008, økte misnøyen blant sekularistene som fryktet en islamistisk overtakelse av staten. Etter å først ha blitt truet av militæret og så på hengende håret overlevd en partistengningssak i Forfatningsdomstolen, vendte Erdoğan derfor oppmerksomheten mot domstolene og generalene. Med god hjelp fra tilhengere av den religiøse lederen Fethullah Gülen, som siden 1999 har bodd i UsA, fikk AKP fjernet en rekke motstandere i militæret og reformert domstolene slik at partiet fikk kontroll over utnevnelsen av dommere og påtalejurister. ${ }^{2}$

AKP vant nok et valg i 2011, men tapte terreng til opposisjonen ved valget $\mathrm{i}$ juni 2015 og måtte utlyse nyvalg for å unngå å måtte danne koalisjonsregjering. I mellomtiden hopet problemene seg opp. I desember 2013 hadde forholdet til Gülen-

Demonstrant utenfor Istanbul tinghus i desember 2017. «Angrep på universitetet er angrep på samfunnet.» 


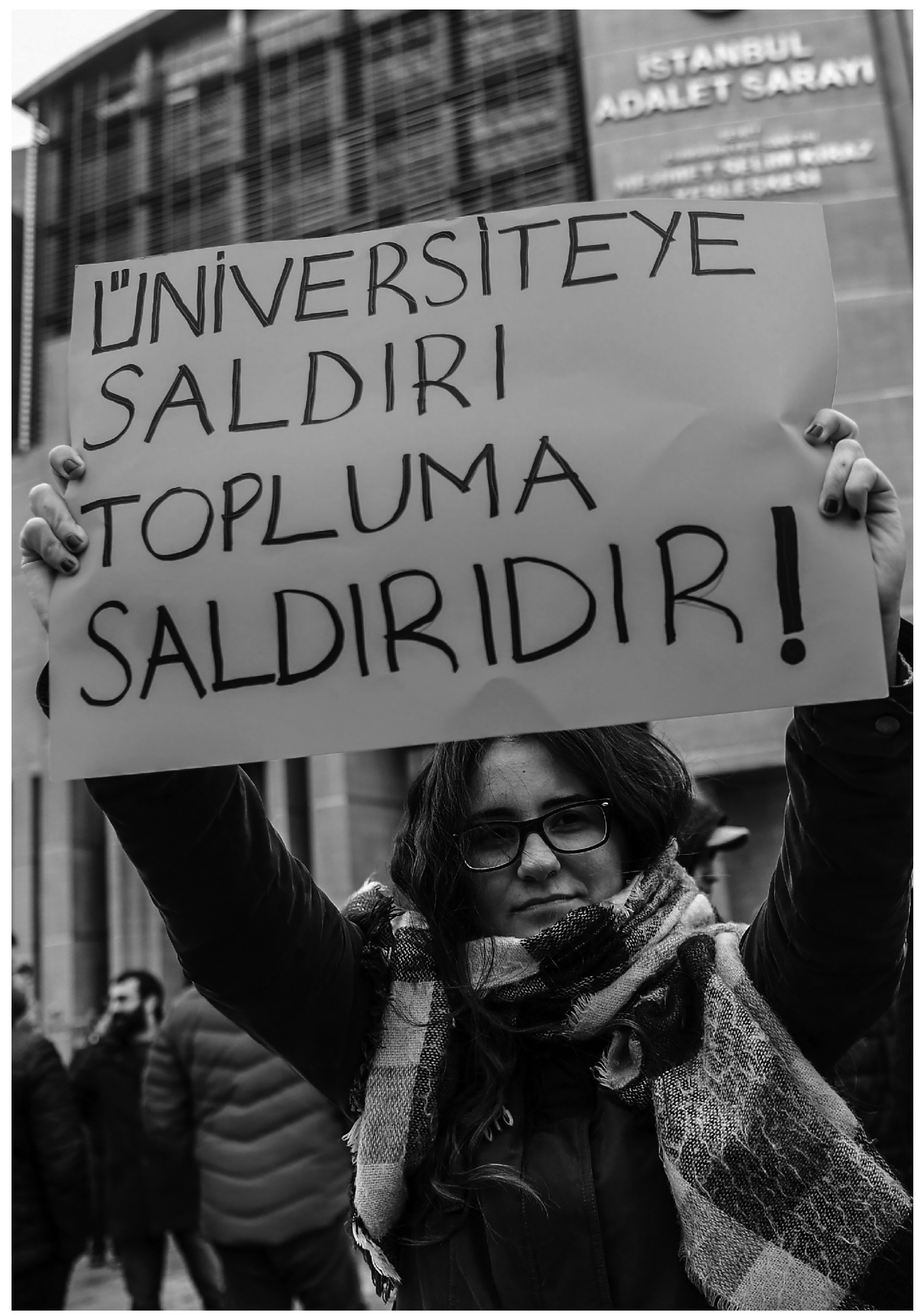


bevegelsen brutt fullstendig sammen, og etter valget i juni 2015 kollapset også våpenhvilen med den kurdiske militsen PKK (Partiya Karkerên Kurdistanê, Kurdistans arbeiderparti). Med anklager om korrupsjon og maktmisbruk hengende over seg, ble det stadig viktigere for Erdoğan å holde på makten. I juli 2016 forsøkte deler av militæret å styrte regjeringen, men feilet. Regjeringen skyldte på Gülen, erklærte unntakstilstand og satte i gang en enorm utrenskning av mistenkte Gülen-tilhengere fra statsapparatet.

Det hele kulminerte i et intenst år hvor opposisjonen ble fullstendig spilt ut på sidelinjen. Først ble det avholdt en kontroversiell ${ }^{3}$ folkeavstemming under unntakstilstanden i april 2017. Her ble det gjennomført 18 endringer i Tyrkias grunnlov som endret styreformen fra et parlamentarisk demokrati til et presidentsystem med en uvanlig sterk president. ${ }^{4}$ Hvem som skulle inneha den nye presidentrollen skulle avgjøres i et valg i november 2019, men allerede i april 2018 avgjorde regjeringen at valget skulle fremskyndes et år til juni 2018, noe som ga opposisjonspartiene bare litt over to måneder til å finne og lansere sine kandidater. Med liten tid til å forberede seg og en enda mindre rettferdig fordeling av ressurser og tilgang på medier enn under folkeavstemningen $\mathrm{i}$ 2017, var det liten tvil om at Erdoğan ville vinne også det valget. Dermed kunne Erdoğan tre inn i en mektigere stilling enn noen tyrkisk politiker har hatt siden Mustafa Kemal Atatürk.

Etter den franske modellen har det lenge vært vanlig å omtale den nåværende tyrkiske stat for den «tredje republikken» fordi den gjeldende grunnloven, som ble kunngjort i 1982, er den tredje i Tyrkias historie etter grunnlovene av 1924 og 1961. ${ }^{5}$ Endringene som ble gjennomført i april 2017 innførte ikke en helt ny grunnlov, men de innebar likevel en stor nok endring i statens struktur til at enkelte beskriver den statsformen som nå er i utvikling som en «andre republikk» - en omkalfatring som visker ut de siste nitti årene med grunnlover og grunnlovsendringer og tar opp igjen den tråden fra 1923, selve «revolusjonen» som førte til at Tyrkia ble en republikk. ${ }^{6}$

På den annen side er det flere jurister som diskuterer om Tyrkia i virkeligheten er i ferd med å gjennomgå en «de-konstitusjonalisering», altså en prosess hvor de viktige endringene ikke ligger $\mathrm{i}$ selve grunnlovsteksten, men i en tendens til at myndighetene ikke lenger anser grunnloven som bindende. Juristen Kemal Gözler peker på en

\section{क \\ Domstolene har fremdeles en rolle å spille, men rollen er åpenbart under endring. Spørsmålet er hvordan.}

rekke mønster som tyder på at myndighetene forholder seg likeglade til grunnloven. ${ }^{7}$ Særlig bekymringsverdig mener han det er at regjering og president i flere år før grunnlovsendringene i 2017 oppførte seg som om landet allerede var gått over til presidentsystem med Erdoğan som president og partioverhode. En viktig grunn til at det var mulig var at domstolene, og særlig Forfatningsdomstolen (Anayasa Mahkemesi), sluttet å legge bånd på den utøvende makt, og at $\mathrm{AKP}$ i de få tilfellene hvor domstolene satte foten ned, simpelthen ignorerte dem. Dette gjorde det i tillegg mulig for AKP-flertallet i Nasjonalforsamlingen å stemme gjennom en rekke lover som åpenbart var i strid med grunnloven.

Debatten om lovens rolle i land som Tyrkia er ikke bare av juridisk interesse. Statsvitere har lenge vært klar over at det finnes avskygninger mellom rene diktaturer, hvor regjeringen setter grunnloven helt til side, og autoritære regimer som gjerne etterstreber å operere innenfor et rettslig rammeverk. Slike rammeverk oppfyller ikke de fleste juristers krav til uavhengighet og rett- 
ferdighet, men gjør likefullt at regimene forblir legalistiske i den forstand at de er opptatt av lover, rettslige prosedyrer og institusjoner. ${ }^{8}$ Det som fra et juridisk perspektiv innebærer at grunnloven mister sin relevans som normativt bindende betyr ikke at lovverket, grunnloven og domstolene blir irrelevante for å forstå et lands politikk.

Gözlers tese impliserer altså ikke at domstolene slutter å fungere. Domstolene har fremdeles en rolle å spille, men rollen er åpenbart under endring. Spørsmålet er hvordan. Hva er domstolenes rolle $\mathrm{i}$ «den andre republikken»? Hvilken effekt har kuppforsøket i 2016 hatt for domstolenes del? For å besvare disse spørsmålene vil jeg gjennomgå noen av de mest dramatiske utviklingene i forholdet mellom A KP og domstolene de siste årene. Med utgangspunkt i Tom Ginsburg og Tamir Moustafas drøfting av domstolers rolle i autoritære samfunn ${ }^{9}$ vil jeg argumentere for at AKPS stat fremdeles er en legalistisk stat, altså en stat som i stor grad styrer gjennom lover og domstoler, og at en slik legalisme har vært et trekk ved Tyrkia lenge før AKP kom på banen. Samtidig er det tydelig at AKP er i ferd med å strekke bruken av domstolene til rent politiske formål så langt at de står i fare for å miste noe av sin nytteverdi som legitimeringsfaktorer for statens bruk av makt. Det betyr ikke at domstolene mister sin rolle, det betyr bare at én av rollene blir særlig markant. Mens tilliten til at tyrkiske domstoler er uavhengige og rettferdige er lav, fungerer de fremdeles som grensesettere for Tyrkias politiske liv, og bidrar dermed til å opprettholde sosial kontroll på vegne av AKP.

\section{ET DRAMATISK BILDE}

En del av utviklingene som for alvor ble lagt merke til av verdenssamfunnet etter kuppforsøket 15. juli 2016, var i virkeligheten godt i gang flere år i forveien. Dette gjaldt særlig anklager om terrorisme og, etter at AKP havnet i åpen konflikt med Gülen-bevegelsen i desember 2013, stengninger av privateide selskaper og utrenskninger av statsansatte i politiet, militæret og domstolene som ble mistenkt for å tilhøre ulovlige organisasjoner.

Antall fanger som var mistenkt for terrorisme $ø$ kte fra 273 under AKPs først regjeringsperiode i 2005 til cirka 13 ooo i 2011, ${ }^{10}$ og hadde allerede nådd 18 ooo innen kuppnatten i 2016. ${ }^{11}$ De fleste av disse fangene var mistenkt for å støtte PKK eller andre grupper på den kurdiske eller radikale venstresiden. Dette kan dels forklares gjennom tyrkiske domstolers tradisjonelle skepsis til sosialistiske og prokurdiske aktiviteter, en skepsis som siden 1980-årene har vært forankret i Forfatningsdomstolens stenging av en rekke politiske partier. ${ }^{12}$ Samtidig har fengslingene hatt en viktig funksjon for AKP. Ettersom de har tillatt regjeringen å fortsette fredsforhandlinger med PKK uten samtidig å måtte bekymre seg for mye om konkurranse ved valgurnen fra fredelige prokurdiske partier som Partiet for et demokratisk samfunn (DTP, stengt i 2009), Freds- og demokratipartiet (BDP, stengt i 2014), og senere Folkenes demokratiske parti (HDP). Mens domstolene enten stengte disse partiene eller desimerte rekkene av aktive medlemmer, kunne АКР bedyre sin respekt for et uavhengig rettssystem og samtidig monopolisere «kurdersaken» gjennom sine samtaler med Рккs fengslede leder Abdullah Öcalan i håp om at en fremforhandlet løsning ville sikre AKP kurdiske stemmer. ${ }^{13}$ Det er verdt å merke seg at selv under «fredsprosessen» i perioden 20112015 viste ikke regjeringen noen reell vilje til å endre de delene av straffeloven som domstolene brukte til å kriminalisere fredelig pro-kurdisk politisk aktivisme, som for eksempel paragraf 7 av Terrorloven og paragraf 216 av Straffeloven. ${ }^{14}$

Men også Gülen-bevegelsen spilte en viktig rolle i å fjerne A KPs politiske motstandere. Gülentilknyttede dommere og påtalejurister var i perioden 2007-2013 nyttige medspillere i AKPs forsøk 
på å fjerne de mest prominente sekularistene blant Tyrkias generaler, og dermed omforme militærvesenet fra en aktiv politisk aktør til en politisk passiv organisasjon. Militæret hadde senest i 1997 oppløst en regjering hvor Erdoğans daværende parti, Velferdspartiet (Refah Partisi), var et koalisjonsmedlem, og satt i gang en prosess hvor Erdoğan havnet i fengsel i fire måneder. Etter at Erdoğan grunnla AKP og ble statsminister i 2003, inngikk han et nært samarbeidsforhold med Gülen-bevegelsen, noe både han og Gülen tjente på. AKP brukte Gülen-bevegelsen som stemmesankere innenriks, og uoffisielle merkevareambassadører for sin vestvennlige form for islam utenriks, mens gülenistene til gjengjeld fikk viktige stillinger i byråkratiet, domstolene og militæret, og forrang i lukrative anbudskonkurranser. ${ }^{15}$ Det var særlig gjennom de såkalte «Domstolene med særskilte fullmakter» (Özel Yetkili Mahkemeler), som AKP-regjeringen opprettet i 2004, at Gülen-tilknyttede påtalejurister og dommere i 2007-2013 fikk makt til å etterforske et påstått ulovlig nettverk innad i staten som både skulle ha stått bak forsvinninger og «falsk-flagg»operasjoner på 1990- og 200o-tallet, og vært i gang med planleggingen av et militærkupp med hensikt å avsette AKP. ${ }^{16}$ Selv om det tidlig ble påvist at mye av bevismaterialet var falskt, resulterte disse rettssakene i flere hundre lange fengselsstraffer for mange av de anklagede.

Først da saken ble anket til Forfatningsdomstolen i 2014 ble det bestemt at den måtte gjenopptas, noe som resulterte $i$ at alle de opprinnelige dommene ble opphevet og de mistenkte ble løslatt. ${ }^{17}$ Det var en avgjørelse enhver domstol kunne tatt på grunnlag av bevismaterialet og prosessfeil alene, men løslatelsen skyldtes nok også en ny politisk atmosfære. I mellomtiden hadde nemlig forholdet mellom Gülen-bevegelsen og regjeringen surnet. ${ }^{18}$ Det foregår fremdeles diskusjoner om hva som forårsaket bruddet, men det er tydelig at
AKPs forsøk på å oppnå en fredsavtale med PKK var et av de viktigste ankepunktene. Enkelte forskere mener at uenighetene skyldtes ideologiske forskjeller mellom Gülens og Erdogans syn på kurderne, ${ }^{19}$ mens andre mener fredsforhandlingene bare fungerte som et påskudd for Gülens tilhengere og at den underliggende konflikten bunnet $i$ en ren maktkamp. ${ }^{20}$ Uansett årsak ble konflikten utløst av at en Gülen-tilknyttet påtalejurist i 2012 kalte inn Hakan Fidan, sjef for etterretningstjenesten міт og Erdoğans høyre hånd, for avhør i forbindelse med hans hemmelige forhandlinger med PкK. Erdoğan reagerte ved å endre lovverket slik at Fidan i praksis fikk immunitet fra etterforskning.

I desember 2013 gikk Gülen-tilknyttede etterforskere ett skritt lenger og utstedte arrestordre på flere sittende ministre i AKP-regjeringen som de anklaget for storstilt korrupsjon. Erdoğan omtalte etterforskningen som et forsøk på et «juridisk kupp» og fikk endret loven slik at regjeringen måtte informeres øyeblikkelig om pågående hemmelige politietterforskninger. Da Hsy K, organet som var ansvarlig for å utnevne dommere og påtalejurister, offentlig protesterte mot lovendringen fordi den undergravde påtalemyndighetens uavhengighet, fikk A K Ps flertall i Nasjonalforsamlingen stemt gjennom en grunnlovsstridig lovendring som ga justisministeren makt til å plassere nok AKP-lojalister i HsYк til at de fikk rokert alle dommerne og påtalejuristene som var involvert $\mathrm{i}$ etterforskningen. ${ }^{21}$ Lovendringen ble annullert av Forfatningsdomstolen i april 2014, men da var skaden allerede skjedd.

For å forhindre at «Domstoler med særskilte fullmakter» igjen utfordret AKPS egne fikk partiet erstattet dem med en ny type rettsinstans i juni 2014, Sulh Ceza Hakimlikleri ( $\mathrm{sCH}$ ), som kan oversettes som «Strafferettslige fredsdommerinstanser». SCH er ikke domstoler, men spesielt utnevnte enkeltdommere som har en rekke 
fullmakter hva angår strafferettslige etterforskninger. De kan blant annet foreta beskyttende tiltak, utstede ransakingsordre, beordre beslagleggelser av eiendom, stenge nettsteder, sette i gang overvåkning og utstede arrestordre. De brede fullmaktene disse dommerne har, kombinert med utnevnelsesprosedyrene og mangelen på reelle ankemuligheter, har fått både tyrkiske jurister ${ }^{22}$ og internasjonale organer som Veneziakommisjonen til å kritisere dem for å bryte med uavhengighetsprinsippet. ${ }^{23}$

Siden konflikten mellom Erdoğan og Gülen ble en offentlig sak i desember 2013, har disse dommerne spilt en viktig rolle i å presse Gülen-bevegelsen opp i det hjørnet de befant seg i sommeren 2016. Det var en scH som i desember 2014 bestemte at Fethullah Gülen, flere journalister og redaktører som jobbet for Gülen-tilknyttede medier skulle arresteres i forbindelse med etterforskningen av den «parallelle statsstrukturen» (Paralel Devlet Yap1s1, PDY), som myndighetene da begynte å kalle Gülen-bevegelsen. ${ }^{24}$ I oktober 2015 bestemte en $\mathrm{sCH}$ at Koza-İpek Holding, som hadde 23 selskap i sin portfolio, skulle overtas av staten og styres av bobestyrere som alle hadde nær tilknytning til AKP. Blant selskapene til Koza-İpek fantes medieorganer som avisene Bugün og Millet, TV-stasjonene Bugün Tv og Kanaltürk. I november samme år besluttet en annen SCH at staten skulle overta kontrollen av Kaynak Holding, som eide 24 selskap, organisasjoner og stiftelser, blant dem Gülen-bevegelsens magasin Sizınt1, som var blitt utgitt siden 1979. I mars 2016, bare tre måneder før kuppforsøket, ble medieselskapet Feza Gazetecilik lagt under bobestyrere sammen med flere medier, blant annet nyhetsbyrået Cihan og avisen Zaman. Zaman hadde eksistert siden 1986, og hadde lokale utgaver i flere land, blant annet Tyskland, usA og Beneluxlandene, noen på tyrkisk og noen på lokalspråket, i tillegg til den engelske utgaven Today's Zaman. I likhet med Koza-İpek og Kaynak var det viden kjent at Feza Gazetecilik tilhørte Gülen-bevegelsen, og at aviser som Zaman i praksis derfor hadde vært en forlengelse av AKPs eget medienettverk frem til bruddet i 2012-2013. Først da Zaman og andre Gülen-tilknyttede medier begynte å kritisere AKP, ble de omtalt som en trussel mot statens sikkerhet og lagt under AKP-tilknyttede bobestyrere, som i de fleste tilfeller stengte dem.

Ettersom scH strekker definisjonen på en «domstol» så langt at det grenser til rene politiske instrumenter, kan man spørre seg om den utstrakte bruken av dem i kampen mot Gülen-bevegelsen egentlig innebærer at AKP-regjeringen allerede før kuppforsøket bidro til å «de-konstitu-

\section{Selv om de politiske kreftene som}

benytter seg av disse instrumentene er

skiftet ut, er instrumentene ganske like.

sjonalisere» regimet. Samtidig er det flere aspekter ved AKPs bruk av «spesielle» domstoler og dekretlover som har lange røtter i tyrkisk historie. Militære eller halvmilitære domstoler har vært en av den tyrkiske generalstabens flittigst brukte instrumenter i kampen mot venstreradikale, prokurdiske eller islamistiske aktivister i flere tiår, noe Erdoğan selv fikk erfare da han i 1999 ble fengslet av en statssikkerhetsdomstol. Selv om de politiske kreftene som benytter seg av disse instrumentene nå er skiftet ut, er selve instrumentene ganske like.

\section{KUPPFORSøKET}

Konsekvensene av kuppforsøket i 2016 kan likevel vanskelig overdrives. Allerede i fire-tiden på morgenen 16. juli, etter at deler av de tyrkiske land- og flystyrkene hadde stanset trafikken i Istanbul, bombet Nasjonalforsamlingen og 
presidentpalasset, beleiret og overtatt militærbaser, politihovedkvarter og TV-stasjoner og drept rundt 300 sivile, landet president Erdoğan på Atatürk-flyplassen og holdt en improvisert pressekonferanse. Med knusende ro forklarte han at «forræderiet» var utført av den samme "parallelle statsstrukturen» han lenge hadde advart mot, og som i førti år hadde infiltrert alle statens institusjoner. Han viste til at domstolene allerede var i gang med å etterforske dette nettverket, og avsluttet med å kalle kuppforsøket en «stor gave til oss fra Gud» (Allah’ın bize büyük bir lütfu) fordi det ga ham muligheten til å en gang for alle å renske ut forræderne fra militæret.

Men utrenskningen begrenset seg ikke til militæret. Fem dager etter kuppforsøket erklærte regjeringen en landsomfattende unntakstilstand (Olağanüstü Hal, forkortet til OHAL). OHAL hadde sist vært gjeldende i de kurdiskdominerte områdene sørøst i Tyrkia fra 1987 og helt frem til 2002, da den nyvalgte AKP-regjeringen opphevet den som et ledd i sin demokratiseringsprosess. I motsetning til militære unntakstilstander, hvor ansvaret for å håndheve loven innenfor visse områder overføres til militæret, innebærer $\mathrm{OHAL}$ at de sivile utøvende myndighetene får utvidede fullmakter til å arrestere og utføre ransakelser, innføre portforbud, forby utgivelser, stanse TV-og radiosendinger og lignende tiltak med den hensikt å håndtere en krisesituasjon. I tillegg kan regjeringen sammen med presidenten utstede spesielle forordninger, på tyrkisk kalt Kanun hükmünde kararnameler (кнк), som gjelder som lov fra det øyeblikket de publiseres i det offisielle lysningsbladet Resmi Gazete. Forordningene som regjeringen har benyttet seg av i stor skala etter kuppforsøket bygger på en grunnlovsparagraf som ble introdusert i 1971, og som, i sin tur, innebar en kodifisering av en praksis med røtter $i$ ettpartistatens autoritære styre i mellomkrigstiden. ${ }^{25}$ I motsetning til vanlige dekretlover be- høver ikke regjeringen noen fullmaktslov fra $\mathrm{Na}$ sjonalforsamlingen for å utstede disse $\mathrm{OHAL}$ - forordningene; Nasjonalforsamlingens godkjenning av unntakstilstanden gjelder i seg selv som en fullmakt. ${ }^{26}$ Forordningene må likevel holde seg strengt innenfor grensene av hva som er nødvendig for å gjenopprette ro og orden, og verken de eller andre tiltak kan gå utover de grunnleggende rettighetene som er nevnt i både den tyrkiske grunnlovens og i Den europeiske menneskerettighetskonvensjonens artikkel 15. I utgangspunktet skulle derfor OHAL være en kriseordning med klare rettslige begrensninger. Regjeringen uttalte også at unntakstilstanden ikke ville ha noen innvirkning på folks dagligliv. ${ }^{27}$

Dette viste seg snart å være en underdrivelse. Allerede 19. juli ble Samanyolu Tv stengt av Det høye rådet for $\mathrm{TV}$ og radio for sin tilknytning til det myndighetene nå kalte «Den fethullaistiske terrororganisasjonen» (Fethullahçı Terör Örgütü),

\section{Denne bølgen av arrestasjoner bærer klart preg av en «føre var»-tenkning hos regjeringen.}

eller ғEтö. Den Gülen-tilknyttede Bank Asya hadde allerede tapt store verdier som en følge av konflikten med Erdoğan før 2016, og fikk 22. juli virksomhetstillatelsen kansellert. Men de virkelig dramatiske utviklingene kom med oHAL-forordninger. Med bare de to første forordningene ble flere titusener av statsansatte suspendert fra jobbene sine, over tre tuseb NGoer, skoler, universiteter, medier og fagforeninger stengt. Og selv om artikkel 148 av grunnloven allerede sier at OHAL-forordninger, i motsetning til vanlige dekretlover, ikke kan overprøves av Forfatningsdomstolen, foretok regjeringen gjennom de første forordningene en ytterligere selvbemektigelse ved 
å erklære at ingen domstol kunne foreta midlertidig forføyning av vedtak som ble tatt med hjemmel i dem, og at tjenestemenn som utfører vedtakene ikke kan holdes ansvarlig på noen måte for sine handlinger.

I skrivende stund er $34 \mathrm{OHAL}$-forordninger (KHK nummer 667-701) utkommet. De fleste av disse består av lange lister med individer som har mistet jobbene sine og som i de fleste tilfellene ikke kan ansettes på nytt i det offentlige. Ifølge nettsiden Turkeypurge.com, som kalkulerer omfanget av utrenskningene utfra offentlig tilgjengelige kilder som Resmi Gazete, har over 170 ooo mistet jobben sin. Først med de siste fire forordningene, fra januar 2018 og fremover, fikk noen av de avsatte stillingene sine tilbake. Forordningene fortsatte å dukke opp med jevne mellomrom frem til oнAL ble opphevet i juli 2018, og ble i løpet av den perioden til og med brukt til å endre lovverket om relativt dagligdagse forhold som bruken av vinterdekk ${ }^{28}$ - langt utenfor det man skulle tro var strengt nødvendig for å hanskes med kuppforsøket.

Det som fra et juridisk synspunkt er mest dramatisk med denne utviklingen er at det store antallet avsettelser, konfiskeringer og tilsettingsforbud har skjedd så å si uten innblanding fra domstolene - et tydelig symptom på «de-konstitusjonalisering». I stedet for å bruke unntakstilstanden som en utvidelse av fullmakter med det spesifikke målet å gjenopprette lov og orden innenfor grunnlovens retningslinjer, har regjeringen simpelthen overtatt funksjoner som normalt skal tilhøre Nasjonalforsamlingen og eksplisitt forbudt domstolene å blande seg inn. At over 4400 av Tyrkias rundt 12 ooo dommere og påtalejurister - inkludert 48 medlemmer av den høyeste forvaltningsdomstolen, Danıştay, 140 medlemmer av den høyeste ankeinstansen for straffesaker, Yargitay, og to dommere fra Forfatningsdomstolen - også fikk sparken de første ukene etter kuppforsøket må utvilsomt ha bidratt til å dempe eventuelle tilløp til opprørstrang hos de gjenværende dommerne.

\section{DOMSTOLENES ROLLE ETTER KUPPFORSøKET}

Likevel har ikke domstolene helt mistet sin funksjon. Parallelt med forordninger som rammer titusener av liv helt uten rettslig prosess har nemlig rundt 150 ooo blitt arrestert, mistenkt for medlemskap i ғETö, og over 80 ooo av dem satt i varetekt i påvente av etterforskning og rettsak. Denne bølgen av arrestasjoner bærer klart preg av en slags «føre var»-tenkning hos regjeringen. Med Gülen-bevegelsen utpekt som makten bak kuppforsøket, må alle som har vært innom nettverket av forretninger, NGoer og utdanningsinstitusjoner som AKP tidligere hjalp Fethullah Gülen med å bygge, først uskadeliggjøres - utsilingen kan man så gjøre senere. Selv om regjeringen ved hjelp av forordninger har forlenget varetektsperioden før fengslingsmøte fra fire til tretti dager ${ }^{29}$ og etter fengslingsmøte fra to og opptil sju år, ${ }^{30}$ innebærer det store antallet arrestasjoner at et stort antall mistenkte nå geleides inn i et allerede overbelastet og underbemannet rettssystem før de enten dømmes til fengsel eller frifinnes. Domstoler har derfor åpenbart fremdeles en viktig rolle å spille $\mathrm{i}$ AKPS nye Tyrkia. Spørsmålet er hva den rollen er og i hvilken grad den kan utføres uavhengig av rent politiske interesser.

Ifølge Tamir Moustafa og Tom Ginsburg kan domstoler oppfylle flere viktige funksjoner for autoritære regimer. ${ }^{31}$ Den mest åpenbare funksjonen er å opprettholde sosial kontroll. Som Martin Shapiro påpekte i sin klassiker Courts, er sosial kontroll en oppgave domstoler er med på å utøve ikke bare i autoritære land, men også i demokratiske samfunn, hvor straffelover gjerne formaliserer et samfunns rådende oppfatning av rett og gal oppførsel. ${ }^{32}$ I autoritære eller semiautoritære land ønsker myndighetene gjerne i til- 
legg å definere kriminalitet i tråd med sine interesser, noe som innebærer at politisk opposisjon også kan falle inn under lovens forståelse av straffbare handlinger. Ettersom det ikke er praktisk for regjering og president å selv håndheve denne forståelsen på stor skala er den beste løsningen å ha et system for rekruttering og utdanning som påser at dommere handler relativt nøytralt når det kommer til konflikter mellom to private parter, men samtidig forblir lojale overfor makthaverne i saker av særlig politisk interesse.

I Tyrkia har makthavernes interesse i å forhindre at visse ideer kommer til offentlig uttrykk i det sivile samfunn eller i politiske partier gjort at særlig straffedomstolene og Forfatningsdomstolen lenge har fungert som redskaper for sosial kontroll. Mens det politiske systemet har utviklet seg fra et autoritært ettpartiregime i mellomkrigstiden til et ustabilt demokrati i nyere tid, har domstolene utvist en kontinuitet både i lovverket de bruker og i dommernes rolleforståelse som beskyttere av statens interesser. ${ }^{33}$ Partier som har forfektet venstreradikale eller islamistiske ideer eller kjempet for kurdisk autonomi har blitt stengt av Forfatningsdomstolen, ${ }^{34}$ mens straffedomstolene har sørget for å signalisere hvor grensene går for offentlige ytringer ved å gjøre livet vanskelig for forfattere, oversettere, journalister og aktivister. ${ }^{35}$

De første årene etter at AKP kom til makten i 2002, håpet mange at partiet kom til å liberalisere lovverket slik at et bredere spekter av politiske standpunkt og identiteter kunne komme til uttrykk. Etter at Forfatningsdomstolen i 2008 truet med å stenge AKP for islamistisk propaganda, begynte AKP-regjeringen i stedet å konsentrere seg om å omforme domstolene på en slik måte at de tolket loven i tråd med partiets interesser i politisk viktige saker, men fortsatte å fengsle de øvrige av statens tradisjonelle fiender, enten de var venstreradikale eller kurdiske. ${ }^{36}$ Etter Erdoğans brudd med Gülen ble også det å tilhøre Gülen-beveg- elsen i praksis kriminalisert, noe som, særlig etter kuppforsøket i 2016, har bidratt til et ytterligere oppsving i antallet mistenkte som må håndteres av straffedomstolene.

Resultatet av AKPs manøvrering mot politiske motstandere er altså at terskelen for å bli fengslet er blitt senket i stedet for hevet. Totalt har antallet fengslede, inkludert både varetektsfengslede og dømte, økt nesten 300 prosent de 16 årene AKP har vært ved makten. ${ }^{37}$ Den store mengden arrestasjoner etter kuppforsøket i 2016 innebærer imidlertid først og fremst en kvantitativ, ikke en kvalitativ endring i domstolenes rolle i å utøve sosial kontroll. Under AKP har pilen lenge pekt oppover.

Legitimering er en annen måte domstoler kan være nyttige for autoritære ledere. Legitimitet er et notorisk sleipt begrep som er vanskelig å måle. Det man imidlertid ganske lett kan observere er i hvilken grad myndighetene på populistisk vis omtaler domstolene som ikke-valgte og derfor illegitime hindre i veien for folkets vilje. Her har det skjedd en endring under AKP. Heller ikke denne endringen sammenfalt med kuppforsøket $\mathrm{i}$ 2016, men har kommet med AKP-elitens gradvis endrede forhold til rettssystemet siden 1990årene, da partiets grunnleggere fremdeles tilhørte Velferdspartiet. Velferdspartiet tilhørte Necmettin Erbakans bevegelse «Nasjonalt utsyn» (Milli Görüş), og ble i 1998 den tredje rekken av lignende partier som siden 1970 ble stengt av Forfatningsdomstolen for å ha fremmet islamistisk politikk. Etter at Erdoğan brøt ut av Erbakans parti og dannet AKP i 2001, holdt han minnet om domstolenes restriktive holdning til politiske partier i live, først ved å love å endre lovgivningen i tråd med Eus og Europarådets anbefalinger, og senere, da Forfatningsdomstolen overprøvde AKPS forsøk på å gjøre rettssystemet mer politisk avhengig, ved å antyde at dommerne var illegitime makthavere som dømte mot nasjonens interesser. Andre i partiet truet også med å fjerne Forfat- 
ningsdomstolen i grunnlovsendringene som var under planlegging. ${ }^{38}$

Strategien ser ut til å ha fungert, for som Bertil Emrah Oder påpeker har Forfatningsdomstolen siden 2010 vist en økende tendens til å ta regjeringens side selv om den i enkelte høyprofilerte saker har motsatt seg AKPs ønsker. ${ }^{39}$ Dette har skjedd i takt med at AKP har omorganisert utnevnelsesprosessen for dommere i hele rettssystemet slik at også Forfatningsdomstolen har kommet under partiets kontroll. ${ }^{40}$ Nå som AKP har konsolidert sin makt over domstolene, har også partiets diskurs med hensyn til domstolenes legitimitet endret seg. På samme måte som Erdoğan tidligere mente at de Gülen-regisserte rettssakene i 2007-2013 var legitime og utenfor regjeringens kontroll, ${ }^{41}$ argumenter AKPrepresentanter nå for at rettsakene mot de nesten 100 ooo som sitter i varetekt anklaget for å være medlemmer av Gülen-bevegelsen, må få gå sin gang uten innblanding fra regjeringen. ${ }^{42} \mathrm{Da}$ den amerikanske pastoren Andrew Brunson ble arrestert i oktober 2016, anklaget for å ha vært i kontakt med, og støttet, både Gülen-bevegelsen og Ркк, forlangte amerikanske myndigheter å få ham utlevert. Erdogan skal da ha tilbudt amerikanske myndigheter en utvekslingsavtale: Brunson mot Fethullah Gülen. ${ }^{43}$ Men på samme måte som amerikanske myndigheter har nektet å utlevere Gülen med henvisning til at amerikanske domstoler er politisk uavhengige, har også Erdogan og andre AKP-politikere hevdet at de umulig kan presse det tyrkiske rettssystemet til å løslate Brunson. ${ }^{44}$ Mens det foregår hestehandel bak kulissene forsøker altså begge sider å legitimere sin utgangsposisjon med henvisning til domstolenes uavhengighet.

\section{KONKLUSJON: GRENSER FOR ENDRING?}

En viktig faktor som må være til stede for at domstoler skal kunne legitimere er at de fremstår som noenlunde uavhengige fra den utøvende makten.
I autoritære samfunn innebærer det i praksis at de en gang i blant må dømme mot regjeringens eller presidentens interesser - ellers blir det for åpenbart at de bare er forlengelser av sistnevntes makt, og legitimerer ingenting. ${ }^{45}$ Med den ustrakte bruken av scH-dommere og Forfatningsdomstolens uvillighet til å stanse bruken av forordninger etter kuppforsøket kan man spørre seg om ikke domstolenes underdanighet til AKP har blitt å tydelig at de er i ferd med å miste sin verdi som redskap for å legitimere partiets maktbruk. En spørreundersøkelse gjennomført av over åtte tusen tyrkiske advokater i 2018 fant at over 83 prosent av advokatene mener at domstolene ikke er uavhengige eller rettferdige, og 82 prosent mente at de var blitt politiserte. ${ }^{46}$ Også blant vanlige borgere er misnøyen stor. En undersøkelse gjennomført for nettavisen Dünya i juni 2018 fant at bare 10 prosent respondentene var fornøyde med domstolene, mens 34 prosent svarte at de ikke var fornøyde i det hele tatt. ${ }^{47}$

At tyrkeres tillit til domstolene er lav betyr imidlertid ikke at domstolene helt mister sin nytteverdi. Særlig straffedomstolene vil sannsynligvis fortsette å fungere som før fordi de utfører oppgaver som er nyttige for Tyrkias utøvende myndigheter. I tillegg til å signalisere for tyrkere hvor grensen går for offentlige ytringer og opposisjonell aktivisme, fungerer de som et landsomfattende, desentralisert nettverk av instanser som samler sammen, vurderer og oppsummerer informasjon om tyrkere som av ulike grunner mistenkes for å ha trådd over grensen for hva regjeringen anser som akseptabelt. Her viser domstolene ingen tegn til å lette på trykket, snarere tvert imot. Sjefen for den tyrkiske Høyesterett İsmail Rüştü Cirit uttalte nylig at så mange som 6,9 millioner tyrkere anses som «mistenkelige» og at etterforskning av 2,5 millioner av dem allerede er i gang. ${ }^{48}$

Jeg har her forsøkt å vise hvordan tyrkiske domstoler lenge har fungert som en viktig arena 
for politiske kamper, og at tendensen til at utøvende myndigheter, enten de er folkevalgte politikere eller militæret, på ulike måter legger press på domstolene i henhold til sine egne politiske prioriteringer, har en lang forhistorie. Spenningen mellom domstolenes legitimerende funksjon og den sosiale kontrollen de utøver som rent legalistiske instrumenter for maktutøvelse har alltid vært tilstede. Med tanke på den skarpe økningen vi nå er vitne til i antallet mistenkte «terrorister» som geleides inn i rettssystemet er det ingen grunn til å tro at domstolene kommer til å miste sin sentralitet med det første.

\section{$\cdot f \cdot$}

JOAKIM PARSLOW er førsteamanuensis i Midtøstenstudier ved Universitetet i Oslo.

1 Ahmet İnsel, "The AKP and Normalizing Democracy in Turkey," South Atlantic Quarterly 102, no. $2 / 3$ (2003): 293308; Ziya Öniş and E. Fuat Keyman, "Turkey at the Polls: A New Path Emerges," Journal of Democracy 14, no. 2 (2003): 95-107.

2 En konsis gjennomgang av Erdoğans konsolidering av makt finnes i Joakim Parslow, "Erdoğan's Turkey: An Unpredictable Partner for a Desparate EU?," Security Policy Library (Oslo: The Norwegian Atlantic Comittee, 2016), atlanterhavs komiteen.no/files/dnak/Documents/Publikasjoner/ 2016/Sikkerhetspolitisk\%20Bibliotek/SPL\%203-2016.pdf.

3 Noen av de mest kritiske ankepunktene mot måten folkeavstemmingen ble gjennomført på finnes i OSCEs rapport: «OSCE, Republic of Turkey, Constitutional Referendum 16 April 2017, OSCE/ODIHR Limited Referendum Observation Mission Final Report», Warszawa, 22. juni 2017, osce.org/odihr/elections/turkey/324816?download=true. Kritikk av selve grunnlovsendringene finnes i «Venice Commission, Opinion on the Amendments to the Constitution Adopted by the Grand National Assembly On 21 January 2017 and To Be Submitted to a National Referendum on 16 April 2017, Opinion no. 875/2017», venice.coe.int/web forms/documents/default.aspx?pdffile=cdl-ad(2017)005-e.

4 Venezia-kommisjonen har laget en uoffisiell engelsk oversettelse av de 18 grunnlovsendringene: «Venice Commission, Turkey: Unofficial Translation of the Amendments to the Constitution. Opinion no. 875/2017», 2. februar 2017. venice.coe.int/webforms/documents/default.aspx? pdffile $=$ CDL-REF (2017)005-e).

5 Man teller da ikke med grunnloven av 1921, som ble ratifisert under Uavhengighetskrigen og gjaldt frem til april 1924, mindre enn ett år etter at Republikken Tyrkia ble proklamert i oktober 1923.
6 Murat Yetkin, «Turkey’s Second Republic,» Hürriyet Daily News, 9. juli 2018. hurriyetdailynews.com/opinion/muratyetkin/turkeys-second-republic-134334; Taner Akçam, «The second republic copies the first Republic of Turkey,» i Ahval, 3. august 2018, ahvalnews.com/turkey-history/secondrepublic-copies-first-republic-turkey.

7 Kemal Gözler, "1982 Anayasası Hala Yürürlükte Mi? Anayasasızlaştırma Üzerine Bir Deneme” (30. mai 2016), anayasa.gen.tr/anayasasizlastirma-v4.pdf.

8 Juan J. Linz, “Totalitarian and Authoritarian Regimes," i Handbook of Political Science, Vol. 3: Macropolitical Theory, red. F.I. Greestein and N.W. Polsby (Cambridge, MA: Addison-Wesley, 1975), 222.

9 Tamir Moustafa og Tom Ginsburg, "Introduction: The Functions of Courts in Authoritarian Politics," i Rule by Law: The Politics of Courts in Authoritarian Regimes, red. Tamir Moustafa og Tom Ginsburg (Cambridge: Cambridge University Press, 2008), 1-22.

10 Aslı Iğsız, "Brand Turkey and the Gezi Protests: Authoritarianism in Flux, Law and Neoliberalism," i The Making of a Protest Movement in Turkey: \#occupygezi, red. Umut Özkırımlı (Houndmills, Basingstoke, Hampshire: Palgrave Macmillan, 2014), 25-49.

11 Statistikk fra det tyrkiske justisdepartementet: adlisicil.adalet.gov.tr/Istatistikler/1996/2016acilanozel.pdf

12 Dicle Kogacioglu, "Progress, Unity, and Democracy: Dissolving Political Parties in Turkey," Law and Society Review 38, nr. 3 (2004): 433-62; Ceren Belge, "Friends of the Court: The Republican Alliance and Selective Activism of the Constitutional Court of Turkey," Law and Society Review 40, nr. 3 (2006): 653-92.

13 Cuma Çiçek, "Elimination of Integration of Pro-Kurdish Politics: Limits of the AKP’s Democratic Initiative," Turkish Studies 12, nr. 1 (2011): 15-26.

14 Derya Bayır, "The Role of the Judicial System in the Politicide of the Kurdish Opposition," i The Kurdish Question in Turkey: New Perspectives on Violence, Representation, red. Cengiz Gunes and Welat Zeydanlıoğlu (Oxford: Routledge, 2014), 27-29.

15 Joshua D. Hendrick, Gülen: The Ambiguous Politics of Market Islam in Turkey and the World (New York: New York University Press, 2013).

16 Joakim Parslow, "Politikk og kriminalitet i det nye Tyrkia," Babylon, nr. 2 2012: 107-19.

17 Anayasa Mahkemesi Genel Kurulu Karar1 18.6.2014. kararlaryeni.anayasa.gov.tr/BireyselKarar/Content/de3fd0d1cced-4a35-8377-750ed661dd6b?wordsOnly=False

18 En detaljert gjennomgang av hvordan forholdet mellom AKP og Gülen har endret seg finnes i Hakkı Taş, "A History of Turkey's AKP-Gülen Conflict,” Mediterranean Politics 23, nr. 3 (2018): 395/402. 
19 Senem Aslan, "Different Faces of Turkish Islamic Nationalism", i The Washington Post, 20. februar 2015.

20 Kumru F. Toktamis, "A Peace That Wasn't: Friends, Foes, and Contentious Re-Entrenchment of Kurdish Politics in Turkey," Turkish Studies, 2018, doi.org/10.1080/14683849.2018. 1500139.

21 Ergun Özbudun, “Turkey's Judiciary and the Drift Toward Competitive Authoritarianism," The International Spectator 50, nr. 2 (2015): 46-49.

22 Kemal Gözler, "Sulh Ceza Hakimlikleri ve Tabii Hakim İlkesi," Güncel Hukuk, October 2014, 46-49.

23 «Venice Commission, Turkey: Opinion on the Duties, Competence and Functioning of the Criminal Peace Judgeships» (Strasbourg: Council of Europe, 2017).

24 «Gülen hakkında kırmızı bülten talebi», Radikal, 19. desember 2014. radikal.com.tr/turkiye/gulen-hakkindakirmizi-bulten-talebi-1254896/

25 Joakim Parslow, "Theories of Exceptional Executive Powers in Turkey, 1933-1945," New Perspectives on Turkey 55 (November 2016): 29-54.

26 Joakim Parslow, "Unntaket som forandrer alt," Klassekampen, 18. august, 2016.

27 «Olağanüstü hal vatandaşlarımızı etkilemeyecek», CNN Türk, 21. juli 2016. cnnturk.com/video/ekonomi/turkiye/mehmetsimsek-olaganustu-hal-vatandaslarimizi-etkilemeyecek

28 Art. 2 av KHK 687, i Resmi Gazete 29974, 9. februar 2017.

29 KHK 667, i Resmi Gazete 29779, 23. juli 2016, og KHK 668, i Resmi Gazete 29783 (2. mükerrer), 28. juli 2016. Varetektsperioden ble noen måneder senere, etter press fra Europarådet, senket til 14 dager (KHK 684, Resmi Gazete 29957, 23. januar 2017).

30 KHK 694, Resmi Gazete 30165, 25. august 2017.

31 Tamir Moustafa og Tom Ginsburg, "Introduction: The Functions of Courts in Authoritarian Politics," i Rule by Law: The Politics of Courts in Authoritarian Regimes, red. Tamir Moustafa og Tom Ginsburg (Cambridge: Cambridge University Press, 2008), 1-22.

32 Martin Shapiro, Courts. A Comparative and Political Analysis (Chicago: Chicago University Press, 1981).

33 Gabriela Knaul, "Report of the Special Rapporteur on the Independence of Judges and Lawyers, Gabriela Knaul" (United Nations General Assembly Human Rights Council, May 4, 2012), 14.

34 Kogacioglu, "Progress, Unity, and Democracy: Dissolving Political Parties in Turkey."

35 Halit Çelenk, 141142 Üzerine (Ankara: Anka Yayınları, 1976), 141; Bülent Tanör, TCK. 142. Madde Düşünce Özgürlü̆̈̈̈ ve Uygulama: Anayasa Mahkemesinin Son Kararı Üzerine Kisa bir Not (Istanbul: Forum Yayınları, 1979).
36 En detaljert gjennomgang av disse endringene finnes i Özbudun, "Turkey's Judiciary and the Drift Toward Competitive Authoritarianism."

37 «Adalet Bakanlığı açıkladı: 15 yılda 223 bin mahpus», i Cumhuriyet, 19. september 2017. cumhuriyet.com.tr/haber/ turkiye/827378/Adalet_Bakanligi_acikladi_15_yilda_223_ bin_mahpus.html\#

38 For eksempel: «Erdoğan'dan Haşim Kilıç’a sert yanıt», CNN Türk, 2. desember 2014 cnnturk.com/haber/turkiye/erdogandershaneler-ugruna-ulkeyi-atese-attilar; «Burhan Kuzu'dan Haşim Kılıç için ağır sözler», CNN Türk, 1. desember 2014 cnnturk.com/haber/turkiye/burhan-kuzudan-hasim-kilicicin-agir-sozler)

39 Bertil Emrah Oder, "Populism and the Turkish Constitutional Court: The Game Broker, the Populist and the Popular," Verfassungsblog, 2. mai 2017, verfassungsblog.de/populismand-the-turkish-constitutional-court-the-game-broker-thepopulist-and-the-popular/.

40 Özbudun, "Turkey’s Judiciary and the Drift Toward Competitive Authoritarianism."

41 «Erdoğan konuştu, partililer uyudu», Milliyet, 21. april 2009.

42 «FETÖ davalarında son durum! Adalet Bakanı: 2 bin 382 sanığa ceza verildi», Habertürk, 16. juli 2018, haberturk.com/tv/gundem/haber/2060782-feto-davalarindason-durum-adalet-bakani-abdulhamit-gul-2-bin-382-sanigaceza-verildi.

43 «Turkey's Erdogan Suggests Swap: Jailed U.S. Pastor For Turkish Cleric», NPR, 29. september 2017, npr.org/sections/ thetwo-way/2017/09/29/554451339/turkeys-erdogansuggests-swap-jailed-u-s-pastor-for-turkish-cleric).

44 «A fist bump, then a rancorous call: How Trump's deal to free an American pastor in Turkey fell apart», The Washington Post, 27. juli 2018. washingtonpost.com/politics/trump-saysus-will-impose-large-sanctions-on-turkey-for-detainingamerican-pastor-for-nearly-two-years/2018/07/26/75dcde32 90e5-11e8-bcd5-9d911c784c38_story.html?utm_term=. deafd $7 \mathrm{~b} 25106$

45 E.P. Thompson, "The Rule of Law," i Whigs and Hunters: The Origin of the Black Act, 1st American Edition (New York: Pantheon Books, 1975), 258-69.

46 «Avukatların çoğuna göre yargıda yolsuzluk var», Milliyet, 10. september 2018, milliyet.com.tr/avukatlarin-coguna-goreyargida-gundem-2739234/.

47 "Vatandaş en çok savunmadan, en az ekonomiden memnun», Dünya, 1. juni 2018, dunya.com/ekonomi/vatandas-en-coksavunmadan-en-az-ekonomiden-memnun-haberi-417841. Spørreundersøkelsen spesifiserte dessverre ikke grunnen til misnøyen.

48 «Yargıtay Başkanı Cirit: 80 milyonluk ülkemizde 6 milyon 900 bine yakın şüpheli var», i T24, 23. november 2017, t24.com.tr/haber/yargitay-baskani-cirit-80-milyonlukulkemizde-6-milyon-900-bine-yakin-supheli-var,496789. 